Claims of Religious Morality

Mawhinney, Alison

\title{
Law and Ethics of Human Rights
}

\author{
DOI: \\ 10.1515/lehr-2016-0014 \\ Published: 01/11/2016
}

Peer reviewed version

Cyswllt i'r cyhoeddiad / Link to publication

Dyfyniad o'r fersiwn a gyhoeddwyd / Citation for published version (APA):

Mawhinney, A. (2016). Claims of Religious Morality: The Limits of Religious Freedom in International Human Rights Law. Law and Ethics of Human Rights, 10(2), 341-365.

https://doi.org/10.1515/lehr-2016-0014

\footnotetext{
Hawliau Cyffredinol / General rights

Copyright and moral rights for the publications made accessible in the public portal are retained by the authors and/or other copyright owners and it is a condition of accessing publications that users recognise and abide by the legal requirements associated with these rights.

- Users may download and print one copy of any publication from the public portal for the purpose of private study or research.

- You may not further distribute the material or use it for any profit-making activity or commercial gain

- You may freely distribute the URL identifying the publication in the public portal ?
}

Take down policy

If you believe that this document breaches copyright please contact us providing details, and we will remove access to the work immediately and investigate your claim. 


\title{
Claims of Religious Morality:
}

\section{The Limits of Religious Freedom in International Human Rights Law}

\author{
Alison Mawhinney*
}

The right to freedom of thought, conscience and religion is not a constant. As human rights law has progressively acquired a conceptual status as a means of reconciling tensions, the substantive legal content of the right to freedom to manifest religion or belief has widened. This paper argues that the admittance of claims of religious morality within this expanded understanding of the right exposes the conceptual imprecision underlying the right and presents a complex challenge to human rights supervisory bodies to address such claims without undermining their founding objectives. The first part of the paper traces the historical treatment of the right to freedom of religion or belief as a means of understanding its evolving and multifaceted nature. Part II draws on this overview to develop a taxonomy of aspects of the right and, in particular, it suggests that claims of religious morality ought to be viewed and treated as a distinct facet. The final part of the paper examines a group of recent cases before the European Court of Human Rights to explore current judicial responses to such claims and considers the risks posed by claims of religious morality for the contemporary right to freedom of thought, conscience, and religion.

\section{INTRODUCTION}

The contestable nature of human rights is nowhere more exposed than in the right to freedom of thought, conscience, and religion. The lack of an agreed philosophical underpinning to the idea of human rights is mirrored and magnified in discussions around the rationale for a right to freedom of religion or belief in human rights law. ${ }^{1}$ A right can live in the absence of a

*Reader in Law, School of Law, Bangor University, Wales. I would like to thank Bob Morris and two anonymous referees for their helpful comments. 
coherent justification for its existence. However, when the issues involving it become increasingly complex there is a need for a fuller agreement as to what the right entails, even if this does not reach a consensus on the reason for its being. There is, after all, a limit as to how much obscuration a court can employ in its interpretation and treatment of the right without fatally damaging the freedom itself and the wider concept of human rights.

A number of recent claims by religious individuals for the protection and accommodation of their beliefs, values, and practices has challenged the European Court of Human Rights to tackle the conceptual imprecision surrounding the right to freedom of religion or belief found in Article 9 of the European Convention on Human Rights (ECHR). ${ }^{2}$ In some instances, the Court has taken the opportunity to clarify its understanding of the scope of the right, and to develop its approach to discerning unjustified interferences with religious freedom. However, the Court has also revealed internal fundamental disagreement over the basic framework of the article and a continuing discomfort with its role in establishing the norms and demarcating the limits of religious freedom in international human rights law. This unease is particularly marked in cases dealing with what have sometimes been called claims of conscience where an individual believes they are required by law to act in a manner contrary to religion. These claims, for example, may relate to views on marriage, abortion, or homosexuality where the view of the claimant finds itself in conflict with the prevailing legislation treating the issue. In the following discussions claims of this nature are referred to as claims of religious morality or, more precisely, as claims stemming from a facet of religion that may be described as "religion as a moral informant."

\footnotetext{
${ }^{1}$ For a discussion of these issues, see, for example, Tom Lewis, What Not to Wear: Religious Rights, the European Court, and the Margin of Appreciation, 56 I.C.L.Q. 395 (2007); see also CAROLYN EVANS, FREEDOM OF RELIGION UNDER THE EUROPEAN CONVENTION ON HUMAN Rights 18 (2003).

${ }^{2}$ European Convention for the Protection of Human Rights and Fundamental Freedoms,

art. 9, Nov. 4, 1950, 213 U.N.T.S. 222, amended by Protocol 3, Sept. 21, 1970, Eur. T.S No. 45, Protocol 5 , Dec. 20, 1971, Eur. T.S. No. 55 and Protocol 8, Jan. 1, 1990, Eur. T.S No 118. (hereinafter ECHR).
} 
Claims arising from "religion as a moral informant” pose significant challenges for the Court. Its first concern is to consider whether claims of religious morality should fall within the scope of Article 9-an unenviable task given the underlying uncertainty as to what the Court ought to be protecting under a right to freedom of thought, conscience, and religion. In the absence of a conceptual underpinning to the right, Part 1 of the paper aims to contribute to a more detailed understanding of its scope through an historical overview of the treatment of religious freedom. The account illustrates the evolving and multifaceted nature of the freedom but, nevertheless, demonstrates that, historically, individual claims of morality have not been an aspect of religious liberty protected by international law.

Part II assesses whether the contemporary formulation of the right to freedom of religion or belief found in Article 9 of the Convention should embrace claims of religious morality. It develops the work of Jeremy Gunn in forming a taxonomy of aspects or facets of religion or belief, drawing on the historical account in the first part of the paper to provide instances when these facets may have received legal protection in the past. It then traces to what extent these various facets are offered contemporary protection by Article 9 and considers the options for admitting and assessing claims of religious morality within the inherent limits of human rights law.

The third and final part of the paper assesses the recent approach of the European Court of Human Rights to claims of religious morality and, in particular, claims of unjustified treatment and dismissal from employment because of a refusal to provide services to homosexuals. It takes as a case study the judgment of Eweida and Others $v$. the United Kingdom and examines the reasoning of the Court through the framework of the taxonomy and assessment provided in Part II. The analysis suggests that a more precise understanding of the relationship between this aspect of religious freedom—“religion as a moral informant” —and the right to freedom of religion or belief would allow for a more appropriate response 
from the Court. The paper concludes with a consideration of the risks posed by claims of religious morality for the contemporary right to freedom of thought, conscience, and religion.

\section{HISTORICAL OVERVIEW OF A MULTI-FACETED FREEDOM}

Religious freedom has been of concern to individuals, states and the international community throughout much of history. A striking feature of this concern has been its variability in terms of the rationale for protection, the recipient of the protection, and the means of realising that protection. A review of the historical development of the protection of religious freedom serves as a reminder and illustration of the flexible and changing nature of rights where formulations of a right are shaped in response to changing ideologies and changing political priorities. Tom Hadden argues that these influences have caused a continual and, at times, cyclical progression in the development of rights. ${ }^{3}$ He notes that rights and concerns associated with minorities, such as religious freedom, "have been subject to what may be called a pendulum effect; that from time to time the focus of attention has shifted from individual to group rights and back again rather like a pendulum." ${ }^{4}$ The position of the pendulum has important implications for how religious freedom is understood and for how claims for the protection and accommodation of religion or belief are treated by law.

The origins of concern for religious freedom in the modern state system can be traced to the development of the idea of religious toleration following the wars of religion in seventeenth-century Europe. The acceptance of diversity in religious belief was initially "a fact which the emerging international community had to accommodate, rather than a

\footnotetext{
${ }^{3}$ Tom Hadden, The Pendulum Theory of Individual, Communal and Minority Rights, 3 CRITICAL REV. INT'L SOC. \& POL. POL'Y 77 (2000).

${ }^{4}$ Id. at 81 .
} 
principle which it sought to uphold.” ${ }^{5}$ Gradually religious freedom also came to be connected to the idea of conscience but, as Julian Rivers notes, relief to conscience was initially provided on a group, rather than individual, basis leading to legal exemptions being provided to certain religious groups, "freeing them from obligations to engage in uniform

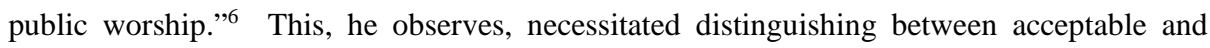
unacceptable dissent. The eighteenth-century philosopher, George Berkeley, expressed this dilemma at the time in a question posed in his work, The Querist: "Whether every plea of conscience is to be regarded? Whether, for instance, the German Anabaptists, Levellers, or Fifth Monarchy men would be tolerated on that pretence?”7 His question not only highlights that the focus at this time was on selecting which groups ought to be awarded an exception from such duties but also that the concern was to grant exemptions to groups rather than to individuals.

Following this period when the emphasis was placed on group rights, the pendulum swung to a concern with the rights of the individual. Hadden suggests that the focus on individual rights reflects the influence of the prevailing political and economic theories in which "individuals were thought to be independent actors who made their own political, social and economic contracts.”8 This shift finds expression in national law rather than in any international treaty. For example, the American Declaration of Independence expresses the eighteenth-century concern for freedom of religion of the individual in the First Amendment: “Congress shall make no law respecting an establishment of religion, or prohibiting the free exercise thereof." While the phrase freedom of conscience is not used in the Amendment it is

\footnotetext{
${ }^{5}$ Malcolm Evans, Religious Liberty and Non-Discrimination, in NON-DISCRIMINATION LAW: COMPARATIVE PERSPECTIVES 119, 122 (Titia Loenen ed., 1999).

${ }^{6}$ Julian Rivers, The Secularisation of the British Constitution, 14(3) ECCLESIASTICAL L.J. 371, 388 (2012).

7 Joseph JoHNSTON, BISHOP BERKELEY's QueRIST IN HistORICAL PERSPECTIVE 182 (1970). Berkeley's work attempted to interrogate the social issues of the time by posing a series of questions and, as Joseph Johnston remarked, for Berkeley, "To formulate the right question was for him a long step in the direction of its ascertainment,” id. at 5.

${ }^{8}$ Hadden, supra note 3 , at 82 .
} 
widely accepted that the "then-contemporary Protestant conception of freedom of conscience underlies these two clauses,"9 albeit with differing opinions on whether the resulting right ought to be interpreted as giving the individual the right to choose her religion or belief in order to avoid the danger of coercion, or whether a better interpretation is to understand the right as a right to exercise a duty according to the dictates of conscience. ${ }^{10}$

During the nineteenth century, with the influence of sociology and socialism, the individualist focus on rights gave way to an approach that focused on national, class, and group rights, and a need for their protection in international law. ${ }^{11}$ In the case of religious freedom, attention centered on the religious minorities of Central and Eastern Europe where territorial settlements were made conditional on states respecting the religious freedom of particular groups within their borders. ${ }^{12}$ The Minorities Treaty (1919) became the prototype for many of the bilateral minority treaties of the inter-war years that aimed to identify and offer protection to religious groups left vulnerable by the terms of political settlements. ${ }^{13}$ It provided a framework that aimed to protect religious minorities from discrimination as well as to guarantee their freedom of religion and cultural accommodation. The latter was provided for in three layers of increasing relevance and specificity to the particular situation pertaining in Poland. First, the free exercise of religion was guaranteed to all inhabitants subject only to public order or public morals. Secondly, minority rights were established in the areas of language use, the establishment of charitable, religious, educational and social

\footnotetext{
${ }^{9}$ Michael J White, The First Amendment's Religion Clauses: 'Freedom of Conscience' versus Institutional Accommodation, 47 SAN Diego L. REV. 1075, 1075 (2010).

${ }_{10}$ Michael Sandel, Religious Liberty - Freedom of Conscience or Freedom of Choice?, 1989 UTAH. L. REV. 597, 611-12 (1989). In arguing for the latter as a better means of protecting the religious liberty of the 'conscientiously encumbered' individual, Sandel is critical of the approach of the U.S. Supreme Court that has favoured the 'voluntarist' conception of the right through an application of the principle of neutrality.

${ }^{11}$ Hadden, supra note 3 , at 82 .

${ }^{12}$ For example, the Treaty of Berlin (1878) which obliged Romania and Serbia-as a condition of their recognition - to respect the religious liberties of all citizens and, in particular, those of their Jewish populations. See Treaty between Great Britain, Germany, Austria, France, Italy, Russia, and Turkey for the Settlement of Affairs in the East: Signed at Berlin, July 13, 1878, , art. XI, July 13, 1878, 153 Consol. T.S. 171.

13 The treaties were to be guaranteed by the League of Nations and enforced as an integral part of international law.
} 
institutions, and in acquiring an equitable share of public funds for their educational, religious, and charitable activities. Finally, two specific "Jewish clauses” provided particular guarantees for the Jewish community in the areas of education and observance of the Sabbath. ${ }^{14}$

The precise nature of the provisions crafted to respond to the position of the Jewish population in Poland—and the similarly specific content of other minority treaties-was possible because, as Malcolm Evans has argued, "the identities of the groups to be protected and the nature of the interests in need of protection were clearly identifiable."15 In such situations, the measures necessary to protect religious freedom could be agreed in concrete form, albeit after intense negotiation. This had the effect of appearing to offer real and generous guarantees of religious freedom and cultural accommodation; these guarantees were later to dissolve with tragic consequences.

Following the events of the Second World War and the associated failure of the minority treaty system, the pendulum swung back to individual rights, but this time at an international level. An emerging body of international human rights law focused on developing general formulations to protect the individual from unjustified state interference. It is when the pendulum came to rest at this point that those concerned with freedom of religion or belief were faced with the conceptual challenge of considering what an individual right to freedom of religion or belief ought to entail and how it ought to be formulated in an abstract, non-concrete manner. As Evans notes, discussions around the drafting of the right to

${ }^{14}$ See Treaty of Berlin, supra note 12, art. 11 (providing that: "Jews shall not be compelled to perform any act which constitutes a violation of their Sabbath,” and included specific reference to attendance at courts of law, and elections or registration for electoral or other purposes).

${ }^{15}$ Evans, supra note 5, at 121. 
freedom of religion or belief in the Universal Declaration of Human Rights ${ }^{16}$ (UDHR) exposed fundamental disagreements:

[W]hich had previously been masked by the exigencies of the particular situation under consideration. For example, the difficulty of defining 'religion' or 'exercise' could be ignored if the primary purpose of a treaty was to ensure that Christians were free to attend a church, Jews a synagogue or Muslims a mosque since ensuring equality between all religions and the freedom of believers to attend worship was quite sufficient. It was unnecessary to be concerned whether it also permitted Animists to have access to nature reserves. Such questions do become relevant when a right is being defined in the abstract.... ${ }^{17}$

While the agreed final formulation of the article (Article 18) did reach a consensus on a number of important issues, ${ }^{18}$ it concealed a variety of understandings as to its substantive content, including disagreement as to when the right could be legitimately limited. Nonetheless, the text and structure of the article gave an indication of the aspects of the freedom that should be protected, even if the meaning and scope of those aspects were left undefined. It reads:

Everyone has the right to freedom of thought, conscience and religion; this right includes freedom to change his religion or belief, and freedom, either alone or in community with others and in public or private, to manifest his religion or belief in teaching, practice, worship and observance.

Article 18 of the International Covenant on Civil and Political Rights (ICCPR) ${ }^{19}$ and Article 9 of the European Convention on Human Rights drew heavily on the text of Article 18 UDHR when translating the Declaration's guarantees into legal obligations. Article 9 of the ECHR provides that:

${ }^{16}$ Universal Declaration of Human Rights, G.A. Res. 217A (III), U.N. Doc A/810 at 71 (1948).

${ }^{17}$ Evans, supra note 5, at 121.

${ }^{18}$ For example, it was agreed that non-theistic beliefs were to be included within its ambit.

${ }^{19}$ International Covenant on Civil and Political Rights, Dec. 16, 1966, 999 U.N.T.S. 171. 
1. Everyone has the right to freedom of thought, conscience and religion; this right includes freedom to change his religion or belief, and freedom, either alone or in community with others and in public or private, to manifest his religion or belief, in worship, teaching, practice and observance.

2. Freedom to manifest one's religion or beliefs shall be subject only to such limitations as are prescribed by law and are necessary in a democratic society in the interests of public safety, for the protection of public order, health or morals, or the protection of the rights and freedoms of others. ${ }^{20}$

The first part of Article 9(1) provides an individual with the absolute right to hold patterns of thought, conscience and religion of their choosing, and to change their religion or belief as they so wish. The remainder of the right provides a right to manifest a religion or belief but this right of manifestation is limited to expression through four channels - worship, teaching, practice and observance. Furthermore, it is articulated as a qualified right subject to a number of limitations as set out in the second paragraph, namely, public order, health, morals, and the protection of the rights of others.

This abstract formulation of an individual right to freedom of religion or belief aims to provide a composite of the range of facets of religious freedom deemed worthy of protection in previous centuries whilst attempting to limit the nature of the claims that fall within its scope. It challenges the European Court of Human Rights to differentiate between those aspects of religious freedom that ought to gain protection from Article 9 and those that should be recognised as outside its scope. As the brief historical account of the treatment of freedom of religion and belief has highlighted, a range of interests has been the object of national and international concern at different points in time. Where individual claims of conscience have explicitly featured as a right, their manifestation has been protected at a national rather than international level. International law has limited its protection of claims

${ }^{20}$ ECHR, supra note 2. 
of conscience to specific groups, for example, those provisions found in minority treaties that permitted Jews to abstain from taking part in activities that would constitute a violation of the Sabbath. In Part II a taxonomic approach attempts to sort the differing interests of the religious freedom into a number of facets with a view to tracing whether and how a contemporary individual human right should accommodate these concerns. In particular, it seeks to examine the place of claims of religious morality—historically often referred to as claims of conscience-within the formulation of such a right.

\section{A TAXONOMY OF THE RIGHT TO FREEDOM OF RELIGION OR BELIEF}

In his work on understanding and recognising claims based on the ground of religion within the context of persecution and discrimination under refugee law, T. Jeremy Gunn suggests that, instead of searching out a definition of religion to assist in identifying such a claim, it is more useful to gain an understanding of the different facets of religion. ${ }^{21}$ He proposes three such facets: "Religion as Belief”; "Religion as Identity”; and "Religion as a Way of Life.” A claim may focus on one of these facets or may involve any combination of them. Gunn recognises that facets other than those he has identified for his specific purposes are likely to exist. The account below develops Gunn's taxonomy and argues that in understanding freedom of religion and belief as an individual human right it is useful to conceive of the "Religion as a Way of life” as being comprised of two sub-facets: "Religion as Expected Conduct” and "Religion as a Moral Informant." It is argued that the latter sub-facet has a particular relevance for contemporary claims of religious morality for accommodation, namely those where the claimant believes the law requires them to act in a manner which is contrary to their religion.

${ }^{21}$ T. Jeremy Gunn, The Complexity of Religion and the Definition of "Religion" in International Law, 16 HARV. HuM. RTS. J. 189 (2003). 
Gunn’s first identified facet, “Religion as Belief,” focuses on an individual’s attachment and adherence to the truth claims of her belief system. Gunn describes this facet as pertaining to:

[The] convictions that people hold regarding such matters as God, truth or doctrines of faith. Belief religion may emphasise, for example, adherence to doctrines such as the Nicene Creed, the transmigration of souls, karma, dharma...Belief religion typically emphasizes the importance of individuals having a proper understanding of doctrines...Although sometimes conflated with so-called "private religion," belief religion may in fact emphasize the critical importance of a religious community of like-minded believers, the essential role of a priesthood in the salvation of souls, or even the need to manifest religion in the public square. But whether belief religion is exhibited by an individual or in a community of believers, it will emphasize the truth claims of the religion. ${ }^{22}$

"Religion as Belief” is recognised and reflected in historical concerns that were often expressed in terms to do with protecting the conscience. From the seventeenth-century, these concerns were alleviated through collective legal exemptions given to particular groups in society excusing members of these groups from general obligations such as the requirement to attend collective public worship according to a prescribed doctrine. This facet is also reflected in the provisions of the inter-war minority treaties that provided for the free exercise of religion and the establishment of religious institutions.

From the perspective of human rights law, protecting "Religion as Belief” demands recognition of the right to choose one's own paradigm of thought, conscience and religion, and the right not to be forced to adopt (if only formally and superficially) alien truth claims. These rights are recognised and protected by Article 9. The right to hold a religion or belief of one's choice is considered by the European Court of Human Rights to fall within the forum internum, an area of inner personal belief that is held to be inviolable and absolute, and

${ }^{22}$ Id. at 200. 
protected by the first limb of Article $9(1) .^{23}$ The Court has rarely considered issues under this aspect of the Article. When it has been asked to consider cases concerning an individual's right not to be forced to adopt unwanted truth claims, it has typically chosen to frame the claim as a passive right not to be forced to manifest beliefs in a manner contrary to one's beliefs. Hence, for example, it chose to consider a case of compulsory religious oath-taking as a violation of Article 9(2), the right to manifest one's religion or belief. ${ }^{24}$ Irrespective of $^{2}$ the mechanism by which claims related to "Religion as Belief" under Article 9 are protected, it should be noted that the Court is essentially concerned here with respecting the right of an individual to believe in a truth, doctrine, or thought pattern of their choosing. It is not concerned with respecting the substantive content of that belief-in other words, the focus is on respecting the person rather than the belief. This renders it unnecessary for the Court to examine the nature and content of a belief prior to affording the individual the right to choose that religion or belief over another.

The second facet identified by Gunn is "Religion as Identity." This facet recognises the role of religion as a marker of group identity as opposed to a source of truth claims and doctrines:

[R]eligion as identity emphasizes affiliation with a group. In this sense, identity religion is experienced as something akin to family, ethnicity, race, or nationality. Identity religion thus is something into which people believe they are born rather than something to which they convert after a process of study, prayer, or reflection. Identity religion, in this basic form, understands co-religionists to be part of the same group (perhaps even regardless of their personal beliefs). Identity religion is less likely to emphasize shared theological beliefs and more likely to emphasize shared

${ }^{23}$ See, e.g., Van Den Dungen v. the Netherlands, App. No. 22838.93, 80 Eur. Comm'n H.R. Dec. \& Rep. 147 (1995).

24 Buscarini et al. v. San Marino, App. No. 24645/94, Eur. Ct. H.R. (1999), where new members of the Parliament were required to take an oath on the Bible that they would fulfil their duties correctly. 
histories, cultures, ethnicity and traditions....this affiliation extends even to those who may be self-consciously non-religious. ${ }^{25}$

The "Religion as Identity" facet of religion was the driver for the protection of religious minorities in the late nineteenth century and the first part of the twentieth century, especially in situations where religion was tied to ethnic identity. In these instances, though not necessarily all, adherence to a particular theology was not the primary impetus for persecution of the individual or group. As Gunn notes, "the persecutor does not attack because of a disagreement over an interpretation of the Nicene Creed or whether enlightenment is best attained through Pure Land or Theravadan Buddhism; the persecutors typically attack because they see the religion of the other as part of a threat to their own competing identity."26

While it is beyond doubt that "Religion as Identity" has been and remains a major cause of discrimination, its treatment as an aspect of the Article 9 human right to freedom of religion or belief adds little to an understanding of what that right entails. The main nondiscrimination article of the ECHR (Article 14) does not confer a free-standing right but rather must be applied in relation to the substantive rights conferred by the other articles in the Convention. Hence, the European Court of Human Rights can only consider a case of religious discrimination in so far as it relates to one of the substantive guarantees found in Article 9. For this reason, Gwyneth Pitt argues that it is more appropriate to treat this facet of religion within the canon of discrimination law through an expanded notion of race and ethnicity. ${ }^{27}$ She commends the approach of the Council of Europe's Framework Convention for the Protection of National Minorities (1995), which recognizes the "Religion as Identity" facet through its conception of national minorities in terms of "the essential elements of their

${ }^{25}$ Gunn, supra note 21, at 201.

${ }^{26} \mathrm{Id}$. at 203.

${ }^{27}$ Gwyneth Pitt, Religion or Belief: Aiming at the Right Target?, in EQUALITY LAW IN AN ENLARGED EUROPEAN Union: Understanding the ARTiCle 13 Directives 202 (Helen Meenan ed., 2007). 
identity, namely their religion, language, traditions and cultural heritage.” For Pitt the advantage of the Framework Convention's approach is that:

[I]t aims not only to protect national minorities from discrimination but also to enable them to maintain and develop their own culture and to promote a climate within which cultural diversity is recognised as a source of enrichment for society rather than being seen as potentially divisive. This approach accurately identifies the central problem of religious discrimination and its precepts would provide a better framework for dealing with it. ${ }^{28}$

While protection of "Religion as Identity" may sit uneasily within the remit of the contemporary individual right to freedom of religion or belief, Article 9 of the ECHR has a significant role to play in the facilitation of the third facet of religion identified by Gunn, namely, "Religion as a Way of Life.” For Gunn, "Religion as a Way of Life” is:

[A]nalytically distinct from the previous two but is likely to be tied to one of them in the mind of the religious person... In this facet, religion is associated with actions, rituals, customs, and traditions that may distinguish the believer from adherents of other religions. For example, religion as a way of life may motivate people to live in monasteries or religious communities, or to observe many rituals including praying five times a day, eschewing the eating of pork or circumcising males...Unlike the once weekly attendance at religious ceremonies, religion for these other people affects many aspects of their lives that are likely not to be accommodated by the laws of a state. Many countries, for example, require military service, which runs afoul of pacifists' strong religious beliefs. ${ }^{29}$

From a human rights perspective and that of Article 9, the "Way of Life" facet of religion is treated through the notion that an individual has a right to manifest their religion or beliefs in worship, teaching, practice and observance, either alone or collectively, and in public or in private. Actions that amount to a manifestation may be subjected to limitations. However, any interference with an individual's right in this manner must be justified by the

${ }^{28}$ Id. at 227.

${ }^{29}$ Gunn, supra note 21, at 204. 
state. If the interference cannot be justified, then accommodation must be made to allow the individual to manifest their religion in the desired manner. The process of justification demands that the state shows that it has met three tests. First, it must show that the restriction on the manifestation was "prescribed by law." Second, it must show that the restriction was imposed in order to protect public safety, public order, health, morals or the rights and freedoms of others. Finally, the state must show that the restriction was "necessary in a democratic society.” The European Court of Human Rights has held that this test of "necessary in a democratic society" requires that the interference corresponds to a "pressing social need” and be "proportionate to the legitimate aim pursued.”30

Given that the majority of claims related to Article 9 fall under the "Way of Life" facet, the question as to what counts as an acceptable form of manifestation of one's religion or belief for the purpose of the right becomes very important. Carolyn Evans notes that the use of specific words without any qualification - "to manifest his religion or belief in worship, teaching, practice and observance"- suggests that the list of modes of manifestation found in Article 9(1) was intended to be exclusive rather than inclusive. ${ }^{31}$

Initially, Strasbourg took a narrow interpretation of what constituted an acceptable manifestation holding that the Article was concerned with protecting "acts which are intimately linked to [religious and belief] attitudes, such as acts of worship or devotion which are aspects of the practice of a religion or a belief in a generally recognised form.”32 This approach is mirrored at the UN level where the UN Human rights Committee has interpreted identical wording in the corresponding Article 18 of the ICCPR as follows:

${ }^{30}$ Handyside v. United Kingdom, 24 Eur. Ct. H.R. (ser. A) at $\S 48$ (1976): "[N]ecessary ... is not synonymous with 'indispensible'... neither has it the flexibility of such expressions as 'admissible', 'ordinary', 'useful'. 'reasonable' or 'desirable'... [I]t is for the national authorities to make the initial assessment of the reality of the pressing social need implied by the notion of 'necessity' in this context."; Serif v. Greece, App. No. 38178/97, (2001) 31 Eur. H.R. Rep. 561 (1999).

${ }^{31}$ Evans, supra note 5, at 105.

${ }^{32}$ C v. UK, App. 10358/83, 47 Eur. Comm'n. H.R. Dec. \& Rep. 142 (1983). 
The concept of worship extends to ritual and ceremonial acts giving direct expression to belief, as well as various practices integral to such acts, including the building of places of worship, the use of ritual formulae and objects, the display of symbols, and the observance of holidays and days of rest. The observance and practice of religion or belief may include not only ceremonial acts but also such customs as the observance of dietary regulations, the wearing of distinctive clothing or head coverings, participation in rituals associated with certain stages of life, and the use of a particular language customarily spoken by a group. In addition, the practice and teaching of religion or belief includes acts integral to the conduct by religious groups of their basic affairs, such as the freedom to choose their religious leaders, priests and teachers, the freedom to establish seminaries or religious schools and the freedom to prepare and distribute religious texts or publications. ${ }^{33}$

In recent times, however, the European Court has adopted a more expansive approach Commented [A1]: : מקור מאומת, קישור: https://www1.umn.edu/humanrts/gencomm/hrcom22.htm

towards identifying acts that should be recognised as "manifestations" for the purposes of Articled 9: "the existence of a sufficiently close and direct nexus between the act and the underlying belief must be determined on the facts of each case. In particular, there is no requirement on the applicant to establish that he or she acted in fulfilment of a duty mandated by the religion in question." 34

This more permissive approach to determining a protected manifestation may be welcomed as an indication of the Court's willingness to accept that a person's religion or beliefs may lead them to believe that they are required to act in a certain manner in many spheres of their life. However, it brings with it added complexity for the application of Article 9. It is suggested here that to understand the nature of the challenges posed, it is useful to subdivide the claims arising under "Religion as a Way of Life" facet into two: “Religion as Expected Conduct” and "Religion as a Moral Informant.”

\footnotetext{
${ }^{33}$ Human Rights Committee, General Comment 22, Art. 18 (Freedom of Thought, Conscience or Religion), para. 4 (forty-eighth session, 1993), U.N. Doc. CCPR/C/21/ Rev.1/Add.4 (1993), adopted by Human Rights Treaty Bodies, U.N. Doc. HRI/GEN/1/Rev.1 at 35 (1994).

${ }^{34}$ Cha' are Shalom Ve Tsedek v. France, App. 27417/95, 2000-VII Eur. Ct. H.R. 231, para. 73 (2000).
} 
Claims arising under "Religion as Expected Conduct" are concerned with protection for conventional—-though not necessarily mandatory-actions and behaviour related to the systems of belief of the claimant. These may include, for example, the right to assemble for collective worship, the right to wear particular items of clothing, the right not to perform military service, and the right to observe days of rest and holidays. ${ }^{35}$ The task of the Court in dealing with these claims is to assess whether restrictions placed on such manifestations are justifiable under the limitations set out in Article 9(2). In this task the Court is not called upon to examine the substance of the underlying belief system that has prompted the manifestation but rather to look at whether the restrictions placed on the conduct are "necessary in a democratic society."36 In short, the approach of the Court is to examine whether the conduct ought to be protected, not whether the belief is worthy of protection.

"Religion as Expected Conduct” encompasses many of the interests that sought legal protection through the centuries, for example, the liberties that were assumed to be protected through the specific clauses of the minority treaties, such as those dealing with education, language use and protecting the Sabbath. It also embraces the concerns of early collective claims of conscience that were granted national protection in the seventeenth-century. These claims relate to the right not to be forced to hold or to worship unwanted truths or doctrinesclaims that originate in the "Religion as Belief" facet but, as noted above, are typically treated as passive manifestations under the scheme of protection developed under Article 9.

The second sub-facet, "Religion as a Moral Informant," is concerned with the desire of an individual to act in a manner consistent with moral convictions that they derive from their religion but which are not directly related with truth claims (the subject matter of the first facet, "Religion as Truth”) nor derived from the expected conduct of that religion. At

${ }^{35}$ See, e.g. Şahin v. Turkey, App. No. 44774/98, 2005-XI Eur. Ct. H.R. 8 (2005); Stedman v U.K., 23 Eur. H.R. Rep. 168 (1997); Bayatyan v. Armenia, App. No. 23459/03, Eur. Ct. H.R. (2009).

${ }^{36}$ ECHR, arts. 8,9, 10, supra note 2. 
times, these convictions may require an individual to refuse to act in a way required by law. For example, they may motivate a doctor to refuse to carry out an abortion or a pharmacist to refuse to distribute contraceptives or a hotel owner to refuse to accommodate same sex couples. For many, an inability to live life in accordance with such convictions can substantially impinge upon their enjoyment of religious freedom.

Historically, claims relating to "Religion as a Moral Informant”-referred to above as claims of religious morality - were not explicitly treated in international approaches to the regulation of religious freedom. At the national level, claims for exemptions from national laws of general applicability have originated from this facet. For example, in England and Wales, legal exemptions on grounds of religion and belief were made available to compulsory medical treatment in $1898 .^{37}$ However, at the level of international human rights law such claims pose a two-fold challenge for an individual formulation of the right to religious freedom.

First, should claims of religious morality be recognised as a protected form of manifestation under Article 9? If the permitted modes of manifestation—worship, teaching, practice, observance - are read strictly and in line with international guidance, it seems unlikely that claims of morality would fall within the notion of an acceptable manifestation. ${ }^{38}$ However, as already noted, the Court has increasingly taken a liberal approach in recognising a wide range of manifestations. ${ }^{39}$ This has been justified as a means of removing the Court from deliberations as to whether a particular manifestation is a mandatory act of a particular religion or belief and, additionally, has allowed for recognition of the fact that many aspects of "Religion as a Way of Life" are central to people's lives. However, arguably this

\footnotetext{
${ }^{37}$ Rivers, supra note 6 , at 389.

${ }^{38}$ See, e.g. Human Rights Committee, General Comment 22, , supra note 33.

${ }^{39}$ Most recentl in Eweida and Others v. United Kingdom, App. Nos. 48420/10, 59842/10, 51671/10, 3516/10,

2013 Eur. Ct. H.R (2013), http:/hudoc.echr.coe.int/eng?i=001115881\&amp;\%7B\%22itemid\%22\%3A\%5B\%22001-115881\%22\%5D\%7D\%20\#\{"itemid":["001-115881"]\}..
} 
expansive approach should be limited to claims arising from "Religion as Expected Conduct" and not extended as far as admitting manifestations under "Religion as a Moral Informant." These latter claims may be more appropriately conceptualised as claims arising from one’s conscience. If this were to be the case then they would not receive protection under the scheme of Article 9 for as Malcolm Evans notes:

[T] he second sentence of Article 9 only relates to the manifestation of a religion or belief and not to the manifestation of patterns of thought or conscience, which are covered by the general right to freedom of expression found in Article 10 of the Convention. ${ }^{40}$

Despite these reservations, the jurisprudence of the European Court of Human Rights shows that claims of religious morality have been deemed admissible. ${ }^{41}$ Unlike claims originating under the "Religion as Truth" facet, these claims cannot expect to receive absolute protection for they involve the manifestation of a religion and belief and no legal system would afford an absolute right to act on such a basis. To determine whether denying the exercise of a manifestation of this type is a violation of the right to freedom of religion or belief, the Court is forced into considering the impact of the manifestation on the rights of others and on society more broadly. And this, in turn, leads to consideration of the second challenge: how should the Court proceed with the balancing act between permitting manifestations of religious morality and protecting public safety, public order, health, morals, and the rights of others?

While the same challenge faces consideration of manifestations arising from "Religion as Expected Conduct," those associated with "Religion as a Moral Informant" generate specific concerns, namely, whether the exercise takes the Court into the arena of

${ }^{40}$ Malcolm Evans, Religious Liberty and InTERnAtional LAW in EuRope 284 (1997).

${ }^{41}$ For example, in the case of two pharmacists who objected to the requirement to sell contraceptives: Pichon and Sajous v. France, App. No. 49853/99, 2001-X Eur. Ct. H.R. 3 (Third Section) (admissibility decision, 2001). 
evaluating beliefs and supporting a particular view of morality. Typically, the Court has endeavored to avoid such tasks and, instead, has seen its challenge as assessing the appropriateness of protecting the individual and manifestation, rather than the belief. However, claims of morality that are based on convictions derived by an individual from their religion may by necessity demand that the nature of those convictions—rather than any underlying truth claims-are examined in order to reach an assessment of how the manifestation relates to others and to "public morality." Without such an assessment, the Court could be seen as too readily accepting, or at least condoning, the morality of the claim, rather than instead accommodating the qualified right of an individual to manifest their religion in this manner. When claims of religious morality impact upon the provision of services, the assessment task becomes further complicated. It raises the argument of whether the individual's claim ought to be accommodated if the service in question can be provided by an alternative person or accessed in an alternative venue. This question has the potential of further drawing the Court into expressing preferred conceptions of morality as part of the process of assessing the appropriateness of accommodating certain convictions in this manner.

The next section aims to illustrate these issues and challenges through an examination of a recent judgement from the European Court of Human Rights that dealt with claims for religious accommodation related to both aspects of the "Religion as a Way of Life" facet: "Religion as Expected Conduct” and "Religion as a Moral Informant.” This examination reaches the conclusion that the treatment of claims deriving from "Religion as a Moral Informant” poses a particular risk for the Article 9 as well as the integrity of human rights law more generally.

\section{THE EUROPEAN COURT OF HUMAN RIGHTS AND CLAIMS OF RELIGIOUS} MORALITY 
In January 2013 the European Court of Human Rights handed down its much-anticipated judgment in Eweida and Others v. the United Kingdom. ${ }^{42}$ The case examined four separate complaints from Christian employees whose rights to manifest their religion as guaranteed in the European Convention on Human Rights had been violated by their employers. All the complaints may be said to be related to the facet of "Religion as a Way of Life," with two falling within "Religion as Expected Conduct" and the other two related to "Religion as a Moral Informant.”

Two of the complaints concerned restrictions placed by employers on the wearing of religious symbols in the workplace. Ms. Eweida, a check-in clerk, wanted to wear a visible cross on a chain in contravention of British Airways' uniform policy. Ms. Chaplin, a nurse, refused to stop wearing a crucifix contrary to her employer's health and safety policy. These complaints may be considered to flow from an understanding of "Religion as Expected Conduct" whereby the wearing of distinctive symbols is seen as a manifestation relating to the observance and practice of religion.

The other two complaints have to do with claims of discrimination in and dismissal from employment because of a refusal to provide services to homosexuals. Ms. Ladele, a Commented [A3]: I suggest after the first time they are registrar, refused to carry out duties relating to the registration of civil partnerships between introduced to use just teir name without Ms. same-sex couples because of her religious objection to same-sex partnerships. Mr. McFarlane, a counsellor, regarded homosexual activity as sinful and thus refused to give a commitment that he would give psychosexual therapeutic counselling to same-sex couples. Complaints of this nature fit within the sub-facet of "Religion as a Moral Informant” whereby an individual feels compelled to act in a manner consistent with their convictions that they derive from their religion or belief.

${ }^{42}$ Eweida, supra note 36. 
The Court's approach in Eweida and Chaplin has been praised for bringing clarity to a number of basic points relevant to a consideration of the ambit of religious or belief freedom. First, the Court noted that if provided "views" seeking Article 9 protection attain "a certain level of cogency, seriousness, cohesion and importance,” then it was incompatible with the state's duty of neutrality for it to "assess the legitimacy of religious beliefs or the way those beliefs are expressed."43 While it did note that there needed to exist a "sufficiently close and direct nexus between the act and the underlying belief,” it recognized that such a nexus must be determined on the facts of each case and, moreover, "there is no requirement on the applicant to establish that he or she acted in fulfilment of a duty mandated by the religion in question." 44 Thus, as Peroni notes, an advantage of this approach is, "that it leaves more room for recognizing minorities within religions, whose practices might not be generally recognized or considered as required by the religion in question." 45

Second, the Court took the opportunity to distance itself from what had become known as the "freedom to resign" doctrine, a feature of Strasbourg's previous approach to freedom of religion cases in the workplace. ${ }^{46}$ In brief, this doctrine had indicated that if a person could avoid the alleged interference with religious freedom through, for example, resigning from her job, then there could be no question of an interference with religious freedom. In Eweida, the Court noted that this option would no longer be a determining factor:

[R]ather than holding that the possibility of changing job would negate any interference with the right, the better approach would be to weigh that possibility in

\footnotetext{
${ }^{43}$ Id. para. 81

${ }^{44}$ Id. para. 82.

45 Lourdes Peroni, Eweida and Others v. the United Kingdom (Part I): Taking Freedom of Religion More Seriously, Strasbourg Observers (Jan. 17, 2013), http://strasbourgobservers.com/2013/01/17/eweida-and-othersv-the-united-kingdom-part-i-taking-freedom-of-religion-more-seriously.

${ }^{46}$ For example, Stedman v. the United Kingdom, (1997), 5 EHRR 544 (1997).
} 
the overall balance when considering whether or not the restriction was proportionate. $^{47}$

Having recognized that Eweida's desire to wear a cross was a manifestation of her religion under Article 9(1), the Court proceeded to examine whether preventing her from doing so could be justified under Article 9(2). Here the Court ought to have considered whether the restriction was imposed to protect one of the legitimate aims found in $9(2)$, namely: public safety, public order, health, morals, or the rights and freedoms of others. However, in place of such a consideration, it readily accepted the aim of the interference as being one of allowing British Airways "to communicate a certain image of the company and to promote recognition of its brand and staff." ${ }^{48}$ It then conducted a superficial proportionality exercise where it concluded that "while this aim was undoubtedly legitimate, the domestic courts accorded it too much weight. Ms Eweida's cross was discreet and cannot have detracted from her professional appearance." 49 The Court concluded there had been a violation of Eweida’s rights under Article 9.

In contrast to this unconvincing approach, the Court is on surer ground in reaching its conclusion in the case of Chaplin. Here, in line with the principles set out in Eweida's case, it recognized that Chaplin's desire to wear a cross at work was a manifestation of her religious belief and that a refusal to allow her to do so was an interference with that right. The Court then looked at the legitimate ground for restricting this manifestation-public health and safety. A cross on a chain might be pulled by a patient thereby injuring the patient or Chaplin, and it may also cause infection by coming into contact with an open wound. ${ }^{50}$ The Court therefore concluded that protecting the health and safety of nurses and patients justified the interference with Chaplin's right to wear a cross on the ward. It felt compelled to add that,

${ }^{47}$ Eweida, supra note 36, at para 83.

${ }^{48}$ Id., para. 93.

${ }^{49} I d$., para. 94 .

${ }^{50} \mathrm{Id}$., para. 98. 
"Moreover, this is a field where the domestic authorities must be allowed a wide margin of appreciation. The hospital managers were better placed to make decision about clinical safety than a court, particularly an international court which has heard no direct evidence." ${ }^{\text {}}$ It is unclear why a reference to the principle of margin of appreciation was deemed necessary given that the Court had reached its own reasoned conclusion based on its case law.

The approach of the Court to these two cases involving claims related to "Religion as Expected Conduct” suggests a methodology that will not question the substantive content of the beliefs involved nor whether the manifestation is one mandated by the religion in question. Rather, the focus in on Article 9(2) and whether the restriction is imposed for a legitimate aim in a manner that is proportionate. While the discussion above suggests that the Court's application of the approach is less than satisfactory in the case of Eweida, overall it indicates that claims for religious accommodation of this nature ought to receive a fuller hearing than under previous procedures. As Mark Hill puts it:

No longer will it be open to defendants to seek a 'knockout blow' by challenging the authenticity of the belief or whether its outward manifestation is doctrinally mandated or by demonstrating that resignation from a particular job would allow the individual the uninhibited practice of his or her religion..$^{52}$

A similar approach can be discerned in the "Religion as a Moral Informant" cases dealt with in the Eweida judgment: Ladele and McFarlane. The analysis below focuses on Ladele given that the facts of this case bring to the fore the range of the concerns highlighted in Part II, that is, a claim of morality within the context of service provision.

Ladele complained that the decision of her employer not to make accommodation for her on account of her objection to same-sex partnerships amounted to breach of Article 14

\footnotetext{
${ }^{51} I d$., para. 99.

${ }^{52}$ Mark Hill, Religious Symbolism and Conscientious Objection in the Workplace, 15(2) ECCLESIASTICAL L.J. 191, 199 (2013).
} 
(right to non-discrimination) of the Convention taken in conjunction with Article 9. The Court stated that in its view "it is clear that the applicant's objection to participating in the creation of same-sex partnerships was directly motivated by her religious beliefs.” It then moved on swiftly to conclude that the "events in question fell within the ambit of Article 9."53 Thus, having recognized Ladele’s objection as a manifestation of her religion, the Court readily accepted that it should be considered as a protected manifestation falling within the scope of Article 9, that is, it accepted that her action was connected to an expression of the worship, teaching, practice or observance of her religion within the meaning of Article 9. It did not pause to consider whether, in contrast to manifestations related to the 'Religion as Expected Conduct' facet, Ladele's objection—being derived from the "religion as a moral informant” facet of religion'-would be better viewed as a manifestation of her conscience on the issue of same-sex couple partnerships, a manifestation that would not have gained the protection of Article 9 .

It is worth noting that the issue of conscience was raised in the Ladele case but in a highly confused manner in the partly dissenting opinion written by judges Vuvinic and De Gaetano. The judges here contended that Ladele's claim should be considered as a "case of conscientious objection,” which they argued could not be subjected to restrictions:

We are of the view that once a genuine and serious case of conscientious objection is established, the State is obliged to respect the individual's freedom of conscience.... No balancing exercise can, therefore, be carried out between the third applicant's concrete right to conscientious objection, which is one of the most fundamental rights inherent in the human person-a right which is not given by the Convention but is recognised and protected by it—and a legitimate State or public authority which seeks to protect rights in the abstract. As a consequence, the Court was not called upon to determine whether the means used to pursue this aim was proportionate. ${ }^{54}$

${ }^{53}$ Ewieda, supra note 36, at para. 103.

${ }^{54}$ Id., para. 6 (Joint Partly Dissenting Opinion of Judges Vucinic and De Gaetano). 
To frame Ladele’s claim in this manner is to fundamentally misunderstand the scheme of protection under Article 9 and to confuse "Religion as Truth" claims with claims belonging to "Religion as a Way of Life.” As noted above, the right to freedom of conscience as found in the human right to religious and belief freedom is a right to not to be forced to hold unwanted beliefs. It is an absolute right. By contrast, the manifestation of beliefswhatever the source of those beliefs-is a right that should always be subject to scrutiny.

Returning to the majority judgement, the Court, having accepted that Ms Ladele’s objection fell within the scope of Article 9, had to now consider whether the policy pursued a legitimate aim and was proportionate. The policy in question concerned the local authority's approach to its task of registering civil partnerships. The aim of this policy was to deliver a service that complied with its Dignity for All policy, which committed the local authority to "the promotion of equal opportunities and to requiring all its employees to act in a way which does not discriminate against others." ${ }^{55}$ It also aimed to deliver a service that was effective in terms of practicality and efficiency. The Court accepted the policy had a legitimate aim and proceeded to consider the proportionality of the means used to pursue this aim. In other words, did this aim justify the interference with Ladele’s right to manifest her beliefs under Article 9 and was the interference proportionate to achieving that aim? It noted that:

The consequences for the applicant were serious; given the strength of her religious conviction, she considered that she had no choice but to face disciplinary action rather than be designated a civil partnership registrar and, ultimately, she lost her job...On the other hand, however, the local authority's policy aimed to secure the rights of others which are also protected under the Convention. ${ }^{56}$

However, in place of a discussion of the proportionality of these issues, the Court then relied on the principle of the margin of appreciation as follows:

${ }^{55}$ Ladele v. London Borough of Islington [2009] EWCA (Civ) 1357 [45] (Eng.).

${ }^{56}$ Eweida, supra note 36, at para 106. 
The Court generally allows the national authorities a wide margin of appreciation when it comes to striking a balance between competing Convention rights... [t]he Court does not consider that the national authorities, that is the local authority employer which brought the disciplinary proceedings and also the domestic courts which rejected the applicant's discrimination claim, exceeded the margin of appreciation available to them. It cannot, therefore, be said that there had been a violation of Article 14 taken in conjunction with Article 9 in respect of the third applicant. $^{57}$

The nature of the Court's approach to the issues in Ladele reveals the complex concerns that arise when "the rights and freedoms of others" is cited as the legitimate aim or ground for an interference with a manifestation relating to "Religion as a Moral Informant." The problem is two-fold. First, there must be evidence that a person's right has been or risks being harmed; the mere causing of offence is not considered sufficient. ${ }^{58}$ As Judge Tulkens has said: "Only indisputable facts and reasons whose legitimacy is beyond doubt-not mere worries or fears-are capable of satisfying that requirement and justifying interference with a right guaranteed by the Convention...[m]ere affirmations do not suffice; they must be supported by concrete examples."59 The reality with claims based on "Religion as a Moral Informant” is that very often they involve providing a service and this service can, at times, be delivered by any number of people. It is therefore possible to avoid causing —and hence difficult to prove-actual or potential harm to an individual.

This issue is at the heart of the Ladele case and other similar "Religion as a Moral Informant" cases: what would have been the nature of the harm if Ms Ladele had been accommodated in a manner which would have allowed her to avoid civil partnership duties? Does the harm equate to the fact that a same-sex couple might be denied the right to a civil

${ }^{57} \mathrm{Id}$.

${ }^{58}$ See Lewis, supra note 1, at 409 (discussing the absence of consideration of harm by the European Court in the case of Leyla Sahin v. Turkey)..

${ }^{59}$ Şahin v. Turkey, supra note 33, para 5. 
partnership? Or, is the harm not the denial of a service but rather the display of discrimination against a group in society on a ground that is protected against such discrimination in national and international equality and human rights law? If the former, then acting to provide an alternative registrar as required for conducting same-sex couples partnerships would protect against this harm. However, if the latter is the case then it becomes difficult to see how the interpretation of the "protection of rights of others" ground, as articulated by Judge Tulkens above, has relevance to such cases. That being so, the remaining other legitimate aim or ground for justification for the interference of Ms Ladele’s right becomes "public morality."

The second difficulty in examining the question of interference on the ground of "rights and freedoms of others" in claims related to "Religion as a Moral Informant" is intrinsically linked to the first; if the question of harm is not addressed, then it becomes impossible to assess whether protecting against this harm is a proportionate act and therefore a legitimate interference with the claimant's right to freedom of religion or belief. In Ladele, the Court avoided a discussion of these issues as well as a potential alternative assessment on the grounds of public morals through taking recourse to the principle of margin of appreciation. $^{60}$ The result was a judgment that avoided any balancing act between interference and aims, and which has subsequently been criticized for its lack of moral reasoning and insight:

[The judgement's] complete lack of reasoning in respect of proportionality and its reliance on the margin of appreciation doctrine makes it problematic. It is problematic

${ }^{60}$ For an argument that the lack of a philosophical underpinning for religious freedom has contributed to the "the adoption of the margin of appreciation as a significant adjudicative tool in this area," see Lewis, supra note 1. 
because the ECtHR can (and regularly does) take the same approach in order to reject claims from sexual minorities about violations of ECHR rights. ${ }^{61}$

\section{CONCLUDING REMARKS: COURTS AND MORALITY}

The accommodation of religious beliefs has been the subject of intense controversy in Europe over recent years. The frequency of cases to do with the right to freedom of religion or belief coming before the European Court of Human Rights has increased, as have the complexity and variety of these claims. A dissection of the complex nature of religion freedom into a number of facets is necessary in order to move towards understanding whether - and howsuch claims should be treated within a contemporary formulation of the right to freedom of religion or belief, such as Article 9 of the European Convention on Human Rights.

Recent case law suggests that claims stemming from the facet of "Religion as a Moral Informant” pose the most difficult challenge for the Court, particularly when such claims occur within the context of service provision. The "alternative provision” argument in these circumstances can appear attractive as a means of avoiding challenging and delicate proportionality assessments. To date, the Court has resisted this temptation. However, having admitted claims to do with the manifestation of religious morality, its subsequent rush to a “margin of appreciation” argument does little to enhance the Court's role as a regional standard-setting body.

In many ways, when faced with claims of religious morality, the Court finds itself in a Catch 22 position—damned if it admits such claims and damned if it does not. If it decides that claims to do with the manifestation of religious morality are inadmissible under Article 9, it may be criticized for failing to take a sufficiently wide understanding of religious liberty

${ }^{61}$ Paul Johnson, Eweida and Others Judgment Part I - The Sexual Orientation Cases, ECHR BLOG, (Jan. 21, 2013), http://echrblog.blogspot.co.uk/2013/01/eweida-and-others-judgment-part-i.html. 
and for failing to offer protection to individuals in important areas of their lives. If the Court does admit such claims but relies too heavily on a "margin of appreciation” argument, it is open to the accusation of cowardice in the face of the need to demonstrate moral leadership and courage. And finally, if it does indeed advance a view on morality in attempting to find a balance between the rights of individuals and public morality, it risks being attacked for preferring that view of morality over another.

Historically, and in contrast to the protection afforded against coercion in truth claims, claims with respect to the manifestation of religious morality have not received protection in international law. When such claims are understood to relate to the "Religion as a Moral Informant" facet rather than to "Religion as Expected Conduct" aspect of religion, then the scheme of Article 9 does indeed provide a strong argument for judging these claims to be inadmissible. Their manifestation does not fall within any of the four categories of manifestation set out in the contemporary formulation of the individual right of religion or belief. These categories are designed to capture those activities (whether doctrinally mandated or not) that are related to the "Religion as Expected Conduct" facet of religion and should be read as an exclusive list of permitted manifestations.

However, cases such as Ewieda demonstrate that the European Court has been willing to admit claims to do with the manifestation of religious morality within the context of service provision. In taking this position, it has to recognize that it has set itself an arduous and hazardous task for it must then be prepared to engage in hard choices in relation to morality. The rights and freedoms of others cannot provide the appropriate ground to assess the proportionality of an interference with a manifestation of this kind. The most apt ground on which to make this assessment will very frequently be that of public morals. However, and unsurprisingly, the judicial process is ill-fitted to make difficult decisions on religion and morality. This is all the more so when it is an international, rather than national, court that is 
charged with performing such an assessment-a task that the majority of the European Court of Human Rights was not prepared to carry out in the Ladele case.

The price to pay for such evasion is high. At one level, an unwillingness to confront the challenge means that a nuanced consideration of the issues does not take place. As a consequence, little guidance is thus made available to those decision-makers who are faced with questions of legal accommodation on a regular basis. At another, deeper level, the avoidance of the question risks bringing the Court and its authority into disrepute. Richard Moon has noted, in relation to the state, that if a state is to take meaningful action, it must prefer some values or moral judgements over others. ${ }^{62}$ Similarly, if the Convention and Court aims to maintain its position as a protector of Europe's human rights, it has to be prepared to engage with morality if it chooses to admit claims stemming from the "religion as a moral informant” facet of religious freedom. This is not to say that an agreed and stable morality, and a proper foundation for legislation can be found in the concept of human rights. ${ }^{63}$ Rather, it forces the Court to refer to, and draw more fully on, its founding principles and to be wary of allowing morality and law to point in opposite directions. ${ }^{64}$ Any future reluctance to do so must surely force the Court into undertaking a fundamental and defining consideration as to whether or not manifestations of claims of religious morality should fall inside the scope of the right to religious freedom in international human rights law.

\footnotetext{
62 Richard Moon, The Supreme Court of Canada's Attempt to Reconcile Freedom of Religion and Sexual Orientation Equality in the Public Schools, in FAITH, Politics AND SEXUAL Diversity: IN CANADA AND THE UNITED STATES 321, 337 (David Rayside \& Clyde Wilcox eds., 2011).

${ }^{63}$ For further discussion of the relationship between human rights law and morality, see MARY WARNOCK, DisHONEST TO GOD: ON KEEPING RELIGION OUT OF POLITICS 111 (2010).

${ }^{64}$ Id. at 89.
} 